\title{
PENGALAMAN PSIKOLOGIS PASIEN INFARK MIOKARD AKUT SELAMA DIRAWAT DI RUANG INTENSIF
}

\author{
Etika Emaliyawati ${ }^{1}$, Titin Sutini ${ }^{2}$, Kusman Ibrahim ${ }^{3}$, Yanny Trisyani ${ }^{4}$, Ayu Prawesti ${ }^{5}$ \\ 1,2,3,4,5 Fakultas Keperawatan Universitas Padjadjaran \\ Email: 1etika@unpad.ac.id
}

\begin{abstract}
ABSTRAK
Infark Miokard merupakan salah satu penyakit terminal yang memerlukan perawatan intensif. Perawataan intensif yang diperlukan harus holistik, mencakup bio psiko sosial dan spiritual. Psikologis infark miokard harus selalu diperhatikan, karena salah satu penyebab infark miokard adalah dari psikologis atau dikenal dengan stress. Tujuan dari penelitian ini untuk mengetahui pengalaman pasien infark miokard akut yang menjalani perawatan di ruang intensif. Jenis penelitian adalah deskriptif kualitatif dengan pendekatan phenomenology yang dilakukan di salah satu rumah sakit di Bandung periode Juni-Juli 2013. Jumlah informan 10 orang pasien infrak miokard akut yang pada saat dilakukan wawancara sudah dalam perbaikan killip I dan II yang diambil secara purposive sampling, dirawat di ruang intensif dan kondisinya telah stabil. Pengumpulan data dilakukan dengan wawancara mendalam kemudian dianalisa menggunakan content analysis dari Hancoch. Hasil penelitian didapatkan 3 tema penelitan yaitu seluruh responden merasa tidak berdaya, 9 responden mengalami ketidakpastian menghadapi masa depan dan 10 responden menyatakan ketakutannya akan kematian. Seluruh pasien infrak miokard mengalami masalah psikologis, oleh karena itu hasil penelitian ini dapat menjadi rekomendasi dalam memberikan layanan kesehatan bagi pasien kondisi terminal; infark miokard akut yang sedang menjalani perawatan intensif. Penting kiranya untuk dapat mengelola dan mengintegrasikan pelayanan perawatan pada pasien infark miokard akut yang sedang dirawat di unit intensif secara holistik meliputi fisik psikologis sosial dan spiritual.
\end{abstract}

Kata kunci: infark miokard akut, pengalaman psikologis, ruang intensif

\section{ABSTRACT}

Communication is a very important process in human relationship. In providing nursing care, nurses should have a good knowledge and communication skill as the beginning of a good relationship between nurses, patients, and their families. Nurses with good communication skill had an easier opportunity to make a good relationship with the patient and their families. This study aimed to identify effective communication barriers among nurses in developing communication with patients' family according to nurses' perspective in Intensive Care Unit Rumah Sakit Umum Al Islam Bandung. This descriptive explorative study involved 10 nurses were taken with accidental sampling. Data were gathered using interview and observation. Data analyzed with the content analysis. Result showed that there were at least five topic of effective communication barriers among nurses in developing communication with patients' family according to nurses' perspective in Intensive Care Unit Rumah Sakit Umum Al Islam Bandung; role conflict, family demographic factors, misunderstanding, environment and situation in the ICU, and family psychological condition. So, training related to communication between nurses and patients' family were necessary to undertake in order to improve the ability of nurses such as foreign language skills and patience in dealing with the situation in the ICU especially in relation to the patient's family. This is because nurses are the spearhead of health care service in hospital.

Keywords: Barriers, ICU, the patient's family, effective communication, \& nurse 


\section{PENDAHULUAN}

Penyebab kematian tertinggi di dunia disebabkan karena penyakit jantung, kedua kanker, ketiga penyakit serebrovaskular dan ke empat adalah pneumonia/influenza Menurut Albrecht (2006). Riskesdas (2009) menuturkan di Indonesia sendiri penyebab kematian terbesar disebabkan karena penyakit jantung, stroke/cerebrovaskular, tuberkulosis, penyakit pernafasan, hipertensi, trauma, penyakit terminal, perinatal, diabetes melitus, dan diare. Dari beberapa penyebab kematian tersebut diantaranya disebabkan karena penyakit terminal/ terminally ill.

Salah satu penyakit dengan kondisi terminal adalah akut miokard infark, penyakit yang disebabkan oleh adanya penyempitan pada lumen arteri koronoria ini menimbulkan nyeri hebat dan dapat menimbulkan kematian secara cepat bila tidak ditangani dengan segera. Penanganan dari penyakit ini adalah menangani nyeri dan penanganan terhadap sumbatan dari arteri koronaria, tetapi itu tidak mutlak menjadikan kondisi jantung pasien menjadi lebih baik. Ketika pasien telah melewati fase kritis dari penyakitnya pada waktu serangan, akut miokard infark masih menimbulkan resiko kematian khususnya pada 6 bulan pertama setelah serangan pertama. Menurut Ahmad., et. al (2006), telah diketahui bahwa gejala-gejala fisik dari klien dalam fase terminal karena penyakitnya, berkaitan dengan peningkatan stres, depresi dan kegelisahan. Distres pada gilirannya dipengaruhi oleh faktor-faktor psikososial dan kultural yang beragam. Pengkajian gejala adanya distres dengan demikian merupakan aspek yang vital dalam perawatan klinis, terutama pada penyakit yang sudah lanjut dan tidak dapat disembuhkan dimana tujuan utama perawatan adalah berkaitan dengan kenyamanan dan kualitas hidup.

Ketika seorang pasien divonis menderita suatu penyakit yang tidak bisa disembuhkan, seketika itu pula kematian sudah berada di pelupuk mata. Sebagai petugas kesehatan dalam hal ini sebagai perawat mempunyai tanggung jawab terhadap segala hal yang menyangkut diri pasien, tentu hal ini tidak bisa dibiarkan begitu saja. Harus ada daya dan upaya untuk mengangkat pasien dari kegelapan dan memberikan harapan walau hanya sementara. Harapan yang dimaksud disini bukanlah harapan untuk kesembuhan dari penyakit yang diderita tetapi harapan untuk mendapatkan kenyamanan dan dukungan dari lingkungan kepada diri pasien dalam menghadapi penyakitnya. Dukungan bisa berupa pemberian semangat dari keluarga, petugas kesehatan, atau yang lainnya sehingga pasien tidak merasa sendiri dalam menghadapi penyakitnya yang dapat merenggut kehidupannya. Dukungan keluarga merupakan faktor yang paling mempengaruhi dalam penanganan psikologis pasien (Clayton, J.M., Hancock, K., Parker, S., Butow, P.N., Walder, S., Carrick, S., et all. 2008). Kecemasan merupakan salah satu masalah psikologis, hasil penelitian Maendra (2014) tentang prevalensi tingkat kecemasan pada pasien Infark Miokard lama di Poliklinik Jantung RSUP Prof. Dr. R.D Kandau didapatkan 48,3\% dari 60 sampel mengalami kecemasan sedang. Masalah psikologis pada pasien terminal seperti infark miokard dapat memperberat kondisi pasien, sehingga memerlukan penanganan yang kompleks.

Penanganan penyakit terminal membutuhkan pelayanan kesehatan yang komplek, mulai dari penegakan diagnosa sampai dengan penanganan dan perawatannya bahkan sampai menjelang akhir kehidupannya. Para dokter berpendapat pasien dengan penyakit terminal ini harus ditangani secara kasuistik tetapi sulit dilakukan dikarenakan mereka tidak atau kurang mengenal setiap pasiennya. Selain itu ada keterbatasan waktu untuk melakukan semua kajian tersebut. Padahal ini terkait dengan bagaimana sebaiknya memberikan perawatan pada pasien dengan penyakit terminal yang akan menghadapi akhir hidupnya untuk memilih perawatan dan cara kematiannya secara terhormat dan bermartabat (Lumenta, 1997). 


\section{METODE}

Metode penelitian yang digunakan adalah penelitian deskriptif kualitatif dengan pendekatan phenomenologi. Teknik pengambilan informan yang digunakan dalam penelitian kualitatif ini adalah purposive yaitu pengambilan informan sumber data dengan pertimbangan tertentu (Sugiyono, 2009). Dalam penelitian ini informan adalah seluruh pasien kondisi terminal dimana penyakit yang tidak dapat disembuhkan/pulih kembali dan dapat menyebabkan kematian.

Kriteria inklusi pada penelitian ini adalah pasien kondisi terminal infark miokard, dengan kriteria (1) Pasien kondisi terminal di sini adalah pasien dengan penyakit jantung yaitu infark miokard akut killip II dan III. (2) Di rawat di unit intensif: CICU dan HCCU. (3)Telah diperkenankan untuk pulang ke rumah oleh dokter penanggung jawabnya. (4) Mampu berkomunikasi dengan baik. (5) Bersedia menjadi informan. (6) Kooperatif

\section{HASIL}

Pengumpulan data dilakukan pada 10 orang informan pasien infark miokard akut yang memenuhi kriteria penelitian. Pengumpulan data dilakukan dengan mengajukan beberapa pertanyaan melalui wawancara mendalam (indepth interview). Pada umumnya wawancara berlangsung selama 60 menit, dengan pembagian waktu yaitu 5 menit pertama membuka percakapan dan mengungkapkan maksud dan tujuan wawancara. Untuk proses wawancara dibutuhkan rata-rata sekitar 45 - 55 menit untuk mengungkapkan apa yang dirasakan dan dibutuhkan oleh pasien selama di rawat di Ruang Intensif Khusus Jantung. Pada 5 menit terakhir untuk mengakhiri proses wawancara. Hasil wawancara yang didapatkan untuk dimensi psikologis pengalaman perawatan yang terungkap dari 10 orang informan meliputi seluruh responden merasa tidak berdaya, 9 responden mengalami ketidakpastian menghadapi masa depan dan 8 responden menyatakan ketakutan akan kematian

\section{Tidak berdaya}

Dari 10 orang informan yang diwawancarai, seluruhnya menyatakan adanya rasa tidak berdaya, seperti yang diungkapkan oleh informan sebagai berikut:

Informan II:

"nyawa saya seperti sudah di leher, sudah tidak berdaya."

Informan IV:

"saya tidak bisa apa-apa, mau berteriak juga suaranya tidak keluar."

\section{Ketidakpastian menghadapi masa depan}

Dari 10 orang informan, 9 diantaranya menyatakan bahwa dengan kondisinya seperti sekarang ini mereka merasakan adanya ketidakpastian dalam menghadapi masa depan. Hal ini dapat terlihat dari pernyataan informan berikut ini:

Informan I:

"saya menangis bila ingat diri saya, di usia sekarang ini, harapan ke depan sepertinya jauh, benar-benar jauh. Bila saya tidak hatihati, tidak menjaga mungkin saya tidak akan bertemu anak saya yang ke dua lulus SD, setiap saat nyawa bisa menjemput saya, karena saya sudah punya faktornya."

“........fisik, pribadi saya sudah tidak kuat, apakah saya mampu membahagiakan mereka."

Informan VI:

"katanya ini penyakit berat, pembunuh sekaligus.....saya belum tau mau ngapain."

\section{Ketakutan akan kematian}

Hasil wawancara yang dilakukan pada 10 orang informan, seluruhnya menyatakan akan ketakutannya dalam menghadapi 
kematian. Hal ini dapat terlihat dari beberapa pernyataan di bawah ini:

Informan XI:

"saya ada kecemasan bila ditinggal sendirian, suka takut pas lagi kambuh gak ada orang, takut meninggal gak ada orang di samping saya."

\section{Informan X:}

"Pasti, pasti ada ketakutan ingatnya ke hal yang jelek, takut terjadi kambuh lagi karena kan manusia biasa, bukan kita tidak mau berumur panjang tapi kalau allah sudah berkehendak apa daya."

\section{PEMBAHASAN}

Pada dimensi ini dari hasil wawancara dengan informan, didapatkan 3 tema penelitian yaitu rasa tidak berdaya dan ketidakpastian menghadapi masa depan dan ketakutan akan kematian. Reaksi psikologis yang dapat muncul dari pasien dengan akut miokard infark sejak pasien menerima informasi tentang keadaan penyakitnya respon pertama awalnya akan merasa tidak percaya, shock, depresi, stress dan marah serta mengalami perubahan kondisi psikologi seperti kecemasan (Caplan \& Sadock, 2005), hal ini sesuai juga dengan penuturan t Kubler Ross, 1970; Glaser, 1972; Lorenz, Lynn, Shugarman, Wilkinson, Mularski, et al. 2008 setelah seseorang diberitahukan tentang penyakitnya yang tidak dapat disembuhkan dan bahwa proses penyakitnya semakin parah, pasien langsung jatuh ke fase depresi. Fase ini dapat berlangsung lama atau cepat tergantung dari faktor usia, pendidikan, agama, lingkungan sosial budaya,faktor ekonomi dan sebagainya. Perubahan kondisi psikologis lain diantaranya: pasien selalu merasa bingung, merasa tidak aman, ketergantungan dan menjadi individu yang pasif. Perubahan kondisi psikologis pada pasien tersebut perlu diperhatikan karena nantinya akan mengancam identitas diri, menyebabkan perubahan peran diri, mengubah citra tubuh dan mengganggu gaya hidup (Smeltzer \& Bare, 2007).

Sejalan dengan hal tersebut melihat dari hasil wawancara informan mengungkapkan rasa tidak berdaya, ketidakpastian pada masa depan, hal ini mencirikan bahwa mereka di fase depresi. Di sini seluruh pasien ketergantungan pada orang lain, baik itu keluarganya maupun petugas kesehatan. Kemudian mereka akan mengalami mekanisme berupa upaya untuk mengatasi keadaan tersebut. Pasien hendak membela diri terhadap informasi yang diterimanya, bersikap mengingkarinya yang segera diikuti dengan sikap menutup diri terhadap semua komunikasi. Pasien tidak mau berhubungan lagi dengan dokter maupun perawat, menutup dirinya terhadap keluarga dan orang-orang lain di sekelilingnya. Sikap tadi dilanjutkan dengan menyatakan kemarahan terhadap orang-orang yang ingin menemuinya. Akhirnya pasien masuk ke fase tawar menawar, pasien menunjukkan keinginan untuk dapat sembuh kembali dan melanjutkan perannya dalam keluarga dan masyarakat. Tetapi keadaan penyakit yang dideritanya mendesaknya terus untuk memahami keparahan penyakitnya. Hal ini mengakibatkan akhirnya pasien masuk kembali ke fase depresi. Pasien menjadi murung, cemas, dan ketakutan, tetapi pada akhirnya dapat menerima kenyataan bahwa penyakitnya tidak dapat disembuhkan kembali. Pada fase depresi ini dapat diberikan therapy farmakologi dan terapi komplementer sebagai alternatif penanganan untuk pasien.

Pasien yang menerima keadaan penyakitnya, masuk ke fase acceptance yang akan diikuti oleh perilaku pasif atau aktif mempersiapkan diri menghadapi apa yang akan dialami. Di samping itu ada pasien yang telah memasuki fase acceptance tetapi masih tetap berusaha dan mengharapkan kesembuhan, upaya ini dinamakan "perjuangan untuk hidup". Tetapi pada akhirnya pasien memasuki proses yang tidak dapat dihindarinya yaitu menjelang akhir hayat. Kelima fase ini selalu disertai dengan 
adanya harapan tentang kesembuhan betapapun kecilnya. Pasien melakukan segala sesuatu untuk memperpanjang usianya dan menganjurkan keluarganya untuk mencari pengobatan baru. Dalam situasi ini orangorang yang dekat dengan pasien seperti keluarga, rohaniawan, perawat dan dokter dapat dengan sangat efektif mempengaruhi pasien. Semua fase tadi dapat berlangsung lama atau cepat tergantung dari faktor usia, pendidikan, agama, lingkungan sosial budaya, faktor ekonomi dan sebagainya.

Seseorang dalam menghadapi kematian akan melewati lima tahap yakni penyangkalan, kemarahan, tawar menawar, depresi dan penerimaan (Ross, 2011). Kondisi- kondisi tersebut jika tidak dipersiapkan dengan baik maka dalam mencapai tahap penerimaan (acceptance) akan sulit dan nantinya tujuan untuk menuju kematian yang bermartabat sulit dicapai (Monks, 2009). Kematian dianggap sebagai akhir dari pelaksanaan tugas-tugas perkembangan, dimana setiap individu memiliki respon yang berbeda dalam menghadapi kepastian datangnya kematian. Death anxiety atau kecemasan kematian merupakan suatu kondisi emosional yang dirasakan ketika suatu hal yang tidak menyenangkan dialami oleh seseorang ketika memikirkan kematian (Templer 1970, Govender 2008). Kecemasan kematian yang tinggi berhubungan dengan output yang negatif seperti gangguan kualitas kehidupan dan kejadian depresi serta terjadinya kecemasan umum. Kecemasan kematian ini juga menimbulkan stres tersendiri bagi keluarga pasien. Hal tersebut nantinya dapat mengganggu perencanaan perawatan dan persiapan untuk menghadapi kematian pasien (Gonen, Kaymak, \& Cankurtaran, 2012). Sehingga sangat penting untuk menentukan batasan dari persepsi tentang kematian tersebut. Persepsi yang berlebihan tentang kematian akan meningkatkan kecemasan kematian itu sendiri dan secara tidak langsung membuat diri individu tersebut menjadi tidak siap dalam menghadapi kematian (Gokler,
Dogan, \& Unsal, 2014). Menurut Satiadarma dan Zamarlita (2008) perasaan cemas terhadap kematian lebih tinggi pada orang yang sakit daripada orang yang sehat. Level kecemasan kematian tergantung pada beberapa hal, diantaranya dari individu tersebut, dari segi kehidupan selama proses penyakitnya berlangsung, dari segi ketika prognosis penyakitnya tidak diketahui, dari ada atau tidaknya hambatan dalam masa penyembuhan, dari durasi penyakitnya serta dari pemikiran akan kematian dan kehidupan (Gokler, Dogan, \& Unsal, 2014).

Ketakutan akan kematian pada pasien akut miokard infark mengalami krisis yang berhubungan dengan perubahan patofisiologi dimana rasa nyeri yang hebat dan disertai sesak nafas membuat pasien berpikir bahwa sekaranglah akhir kehidupannya, selain itu pengobatan yang diperlukan dan atau situasi yang mempengaruhi seseorang membuat pasien memiliki pikiran negatif. Selain perubahan patofisiologi, penanganan pasien infark miokard memerlukan penanganan cepat dan tepat karena terlambat saja penanganan yang diberikan dapat berakibat fatal situasi ini sangat mempengaruhi pikiran pasien. Apabila pasien dihadapkan pada kematian, maka keyakinan spiritual dan keinginan untuk sembahyang / berdoa lebih tinggi (Hamid, A.Y.S S. Hamid. (2000)). Faktor-faktor yang berhubungan dengan kecemasan kematian ini berdasarkan pada penelitian- penelitian yang telah banyak diteliti diantaranya: usia, jenis kelamin, lingkungan, keyakinan agama (Lonetto, R \& Templer, 1986), dukungan sosial (Henderson, 2009), budaya (Lehto, R. H, \& Stein, K. F, 2009), pendidikan dan pekerjaan (Khawar, M., Aslam, N., \& Aamir, 2013), serta kondisi fisik (Yuliana, 2015). Menurut beberapa penelitian melaporkan bahwa tingkat kecemasan kematian sangat tinggi pada pasien dengan gangguan mental seperti depresi dan cemas, namun disisi lain, dilaporkan bahwa pasien dengan penyakit kronik seperti kanker, jantung dan pasien dengan hemodialisa cenderung memiliki 
tingkat kecemasan akan kematian yang tinggi pula (Beydag, 2012). Oleh karena itu hendaknya perawat dapat mengoptimalkan kualitas hidup pasien terminal dengan memfasilitasi pasien untuk dilakukannya express feeling, karena menurut penelitian yang dilakukan oleh Susan (2000) bahwa pasien-pasien dengan penyakit kronis mengaku senang dan bersyukur mendapatkan kesempatan untuk saling tanya jawab dan membicarakan topik tentang kematian. Menurut pendapat mereka umumnya para tenaga kesehatan disana takut dan lebih memilih untuk menghindari pembicaraan tentang kematian dengan pasien sehingga pasien menjadi kurang bisa melakukan express feeling dan akhirnya dapat lebih meningkatkan rasa kecemasan terhadap kematian itu sendiri (Adelbratt \& Strang, 2000).

\section{SIMPULAN DAN SARAN}

Kesimpulan dari penelitian pengalaman pasien kondisi terminal: infark miokard akut selama di rawat di Ruang Cardiac Intensif Care Unit (CICU) Rumah Sakit Hasan Sadikin Bandung dilihat dari 4 dimensi yaitu dimens fisik, dimensi psikologis, dimensi sosial dan dimensi spiritual. Untuk dimensi fisik didapatkan tema penelitian nyeri dada dan sesak nafas. Untuk dimensi psikologis didapatkan tema penelitian tidak berdaya dan ketidakpastian menghadapi masa depan. Sedangkan untuk dimensi sosial didapatkan tema penelitian yaitu tidak dapat ditemani keluarga, pesan kelangsungan hidup keluarga, dan biaya besar untuk berobat. Sedangkan untuk dimensi spiritual didapatkan tema penelitian ketakutan akan kematian dan kesulitan dalam melaksanakan ibadah (sholat).

Saran dari penelitian ini adalah pentingnya dapat mengelola dan mengintegrasikan pelayanan perawatan pada pasien infark miokard akut yang sedang dirawat di unit intensif secara holistik; bio psiko sosial dan spiritual.

\section{DAFTAR PUSTAKA}

Ahmad, N., Kamal, M., Anwar, A.H.M.M., and Rahman, A.K.M.S. (2006). Needs Of Terminally Ill Patients And Their Families: An Experience With Fifty Three Patients Attending A Newly Organized Palliative Care Service In Bangladesh. Journal of BSA, Volume 19, No. $1-2$.

Adelbratt, S., \& Strang, P. (2000). Death anxiety in brain tumour patients and their spouses. Palliative medicine, 499-507.

Albrecht, C. (2006). Overview of The South African Cancer Research Environment As A Basis For Discussions Concerning The Activation of CARISA ( Cancer Research Initiative of South Africa). Independent Medical Research Consultant

Caplan, \& Sadock, B. (2005). Ilmu Kedokteran Jiwa Darurat. Jakarta: Widya Medika.

Clayton, J.M., Hancock, K., Parker, S., Butow, P.N., Walder, S., Carrick, S., et all. (2008). Sustaining hope when communicating with terminally ill patients and their families: a systematic review. Psycho-Oncology 17: 641-659

Gonen, Kaymak, \& Cankurtaran. (2012). The factors contributing to death anxiety in cancer patients. J Psychosoconcol, 30: 347-358.

Glaser, G. (1972). Disclosure of Terminal Illness In: Patient, Phisician and Illness. Free Press New York.

Govender, M. (2008). Death Anxiety and Attitude of Nurses towards Dying. The Gerontological Society of America Vol 45.

Hamid, A.Y.S S. Hamid. (2000). Aspek Spiritual dalam Keperawatan. Widya Medika : Jakarta. 
Hawari, D. (2004). Doa dan Dzikir Sebagai Pelengkap. PT. Dana Bhakti Prima Yasa : Jakarta

Hawari, D. (1996). Al-Quran: Ilmu Kedokteran Jiwa.dan Kesehatan Jiwa PT. Dana Bhakti Prima Yasa : Jakarta Khawar, Aslam, \& Amir. (2013). Perceived Social Support and Death Anxiety Among Patients with Chronic Diseases. Pakistan Journal of Medical Research, 75-80.

Lumenta, B. (1997). Tanatologi tentang Perilaku Pasien Terminal. Ebers Papirus-Vol 3. No.1

Lonetto, R., \& Templer, D. ( 1991). Death Anxiety. Washington: Hemisphere Publishing Corporation.

Monks. (2011). Psikologi Perkembangan. Yogyakarta: Gadjah Mada University Pres.
Ross, K. E. (2011). Death and Dying. New York: Simon and Schuste.

Smeltzer \& Bare (2007). Brunner \& Suddarth's texbook of medical surgical nursing. Philadelphia: Lippincott Williams \& Wilkins.

Sugiyono. (2014). Metode Penelitian Kuantitatif dan kuantitatif. Bandung: Alfabeta.

Yuliana. (2015). Mengatasi Kecemasan terhadap Kematian pada Pasien Sakit melalui Konseling Kelompok. Seminar Psikologi \& Kemanusiaan , 458-463. 